IJAMSR 3 (6) www.ijamsr.com CrossRef: https://doi.org/10.31426/ijamsr.2020.3.6.3414

\title{
A STUDY OF USING SOCIAL MEDIA TOWARDS DEVELOPMENT OF MODERN MARKETING TRENDS: OPPORTUNITIES AND ISSUES
}

\section{Dr. Narendra Kumar}

Asst. Professor, Dept. of. Commerce, Maharani’s Arts, Commerce and Management Women's College, Banagalore, India.

Email: 6narendrakumar@gmail.com

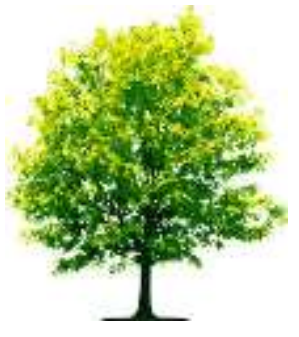

Keywords:

Media Tools, Modern Marketing,

Online Marketing,

Social Media, Develop,

Opportunities, Issues.

\section{A B S T R A C T}

The present stage in the advancement of the Internet has upset the manner in which people impart, collaborate, and share information has drastically changed the manner in which customers search for and purchase products. The social media has changed the power structures in the Modern market place. Social media are methods for purchasers to share text, images, audio and video information with one another and with organizations and the other way around. With the ascent of social media marketing as a significant area of training and research, a developing number of academic and professional articles have risen featuring best practices in social media in Modern marketing. Along these lines, business must figure out how to utilize social media in a manner that is reliable with their field-tested strategy. This is particularly valid for organizations endeavoring to increase an upper hand. The ubiquity of social media for Modern marketing purposes can be ascribed to various preferences related to social media when contrasted with customary Modern marketing channels.

Citation: Dr. Narendra Kumar (2020). A Study Of Using Social Media Towards Development Of Modern Marketing Trends: Opportunities And Issues. International Journal of Advanced Multidisciplinary Scientific Research (IJAMSR) ISSN:2581-4281, 3 (6), June 2020, Pp 31 - 44 
IJAMSR 3 (6) www.ijamsr.com CrossRef: https://doi.org/10.31426/ijamsr.2020.3.6.3414

\section{International Journal of}

Advanced Multidisciplinary Scientific Research (IJAMSR) ISSN:2581-4281

\section{Introduction}

Social media as "a gathering of Internet put together applications that work with respect to the ideological and technological foundations and permit the creation and trade of client produced content." Social media are methods for consumers to share text, images, audio, and video information with one another and with organizations and the other way around. Social media enable marketers to build up an open voice and nearness on the web and fortify other communication exercises. Due to their everyday immediacy, they can likewise urge organizations to remain imaginative and important. Along these lines; business must figure out how to utilize social media in a manner that is consistent with their business plan. This is particularly valid for organizations endeavoring to increase an upper hand. The fame of social media for marketing purposes can be credited to various preferences related with social media when contrasted with traditional marketing channels.

$92 \%$ of marketers pronounced that social media marketing assumes an essential job for their business. $97 \%$ of marketers are indicating enthusiasm by taking an interest social media
(Report by social media analyst). $62 \%$ of the marketers said Social media assumed unique job in marketing recent months (State of Inbound marketing, 2012). By and by, Companies that got clients are from Social media. $80 \%$ of the system clients want to connect marks through Facebook. According to the Statistics a normal of 42 minutes were spent by clients on Facebook every day. The above insights shows a huge imminent of social media marketing to flood deals.

As per the ongoing examinations, organizations perceived the significance and job of social media marketing and intended to build social media spending plans for next 5 years. It is a best medium to convey our information effectively and successfully online. From last 7 or 8 years we have seen an abrupt increment and progression on Social Media destinations. By and by the most expanded Social media systems are Facebook, Twitter, Google+ and LinkedIn etc.

India is World's 7th largest in Internet Market; there are 21 million people in India who are estimated to visit social media sites regularly which are $60.3 \%$ of the total active Indian Internet audience. More than $90 \%$ of Indian 
IJAMSR 3 (6) www.ijamsr.com CrossRef: https://doi.org/10.31426/ijamsr.2020.3.6.3414

online users belong to $18-45$ age groups which has high purchase power and high disposable income. The social media websites in India are growing by almost $100 \%$ year after year.

\section{Tools Of Modern Marketing}

Modern marketing utilizes Digital marketing. It could be clarified as a marketing that utilizes electronic gadgets, for example, personal computers, smartphones, and cellphones, tablets Television sets TV and game consoles to connect with partners. A component of Digital marketing is Digital Brand Engagement. Digital marketing applies advancements or stages, for example, websites, email, applications and social systems [1]. Digital Marketing can be through Non-internet channels likewise like TV, Radio, SMS, or through Internet channels like Social Media, Esends advertisements, Banner promotions. Social Media Marketing is a component of digital marketing. Numerous organizations utilize a combination of traditional and digital marketing channels however notwithstanding, digital marketing is getting progressively well known with marketers as it enables them to target and track numerous angles remembering their Return for Investment (ROI) all the more precisely contrasted with other traditional marketing channels. Digital Marketing is the utilization of digital channels to advance or market items and administrations to consumers and businesses. A transformation of marketing is in progress as we invest more energy in our mobiles, tablets and PCs. The test for brands is to connect with clients through every one of these gadgets progressively and make crusades that work crosswise over social media, show publicizing and web based business [2].

The ongoing conversations brands have with individuals as they cooperate with websites and versatile applications have changed the idea of marketing. The modern-day marketing office needs to join the imaginative side of the order by utilizing incredible accounts to take advantage of individuals' desires and aspirations with the specialized side of information, digital building and investigation. The two zones don't generally sit effectively together. Getting inventive marketers to work alongside specialized staff can be an immense test. Three territories of marketing which have been changed by digital are the speed, pertinence and reach of battles. Digital marketing has likewise enormously expanded significance [3]. Messages can be focused with 
IJAMSR 3 (6) www.ijamsr.com CrossRef: https://doi.org/10.31426/ijamsr.2020.3.6.3414

\section{International Journal of}

Advanced Multidisciplinary Scientific Research (IJAMSR) ISSN:2581-4281

a laser center to quite certain gatherings offering them applicable content. The scope of battles has additionally expanded significantly. With such a significant number of various ways that clients get to media, regardless of whether through Facebook, YouTube, news websites, by means of versatile or tablet applications, a strong thought can rapidly increase tremendous scale. Marketers need to refresh their aptitudes so as to benefit as much as possible from these quick moving and profoundly pertinent battles through digital. They have to work intimately with information experts, web engineers and social media professionals. The advertiser of things to come needs to consolidate marketing and inventive abilities with a comprehension of continuous innovation. Similarly as marketers need to become savvier about innovation, information and investigation, so the in fact disapproved of staff on the digital side need to get progressively imaginative and they are meeting people's high expectations. An essential quality for marketers in the quick changing digital environment is interest, instead of a particular specialized information. For brands to work adequately together in the digital world, head marketing officials and boss information officials work in unison. Be that as it may, this is difficult to accomplish for some organizations and the different sides can wind up in conflict. Unadulterated digital players, for example, Net-a-Porter that have consistently been digital are organized for the digital age [4]. Searching for a vocation in marketing must be set up to unite the enchantment of marketing and the study of innovation to make ground-breaking and pertinent marketing efforts. The present connected consumers are utilizing smartphones, iPads, PCs and even glasses and watches to get to content. Subsequently, marketing offices need to give convincing efforts over these various gadgets and become capable in utilizing innovation [5]. Marketers work intimately with IT divisions and technologists. They comprehend the procedures behind creating websites, dealing with information and running social media crusades. The board talked about how marketers could build up the aptitudes to empower them to work connected at the hip with technologists while holding their innovativeness, pizazz and intuition. 
IJAMSR 3 (6) www.ijamsr.com CrossRef: https://doi.org/10.31426/ijamsr.2020.3.6.3414

\section{International Journal of}

Advanced Multidisciplinary Scientific Research (IJAMSR) ISSN:2581-4281

\section{Opportunities By Social Media Marketing}

\section{Blogger/ Copywriter}

The post and articles you read on the internet were written by people. Working as a blogger or online writer means managing a varied workload and keeping track of plenty of deadlines, but it's hard to argue with the convenience of working from your home computer.

\section{App Developer}

App development is typically a humble field but offers a significant potential for success. A great idea, if given enough effort and exposure, can grow a tiny start-up into a wildly popular social media giant. At the very least, though, developers can be satisfied knowing that their work is making the Internet a better, more diverse place.

\section{Web Designer}

A great idea for the Next Big Thing in social media may be technically sounds, but it won't do much good unless it's presented in an accessible, user - friendly package. This is where the web designer comes in. Designers create the layout and aesthetic of a site, essentially building a bridge between the codes that makes the site work and ordinary users.

\section{Hacker/Security}

Specialist It's generally more about stealing and destroying top-secret files, extorting money from large corporations and government institutions, and more often than not, flying through wire-frame environments. The reality is a lot less fantastic, but real-world hacking is invaluable to today's social media and is an honest, paying job, to boot.

\section{Digital Marketer}

Digital marketers focus on the critical task of studying internet trends and using them to cleverly draw traffic to a particular site. As social media's influence on society has grown, more and more businesses have recognized the importance of building their web presence, so opportunities for digital marketers are more widespread than ever.

\section{Issues Of Social Media Marketing}

- Choosing appropriate Brand Ambassador for the organization.

- In social media it involves high budget to promote product effectively. 
IJAMSR 3 (6) www.ijamsr.com CrossRef: https://doi.org/10.31426/ijamsr.2020.3.6.3414

\section{International Journal of}

Advanced Multidisciplinary Scientific Research (IJAMSR) ISSN:2581-4281

- Ignorance of advertisements from customers in social media to save time.

- Faceless relationships with customers.

- Fake news and false promises in social media leads to decrease in reputation of organization.

\section{Few Popular Social Media Networks}

\section{Facebook}

- Marketing campaigns on Facebook can make your social presence more visible and vivacious.

- FB marketing solutions consists of integrated Facebook advertising campaign, Facebook application development, page design, paid advertising, viral marketing and a lot more.

\section{Twitter}

- Twitter provides innovative marketing services which can help to increase your followers and make your products and services more visible in several social media platforms.

- It provides your business to engage your product or service with millions of users at a time.

\section{LinkedIn}

- LinkedIn promotes services helps you link with your targeted audience.

- The innovative strategies and ideas can play an active role in enhancing your social presence and make it better than your opponent.

\section{Google+ and You Tube Marketing}

- Google+ and YouTube offers an exciting opportunity by which any organization can competently promote their business.

- By using these networking platforms, we promote the services and products of our clients and improve their visibility and brand equity online.

\section{Comparison Of Buying Behavior Of Customer}

It's interesting to observe the buying patterns of Customers in old days and in current situation. The reveals some facts about changing in buying pattern of Customer. 
International Journal of Advanced Multidisciplinary Scientific Research (IJAMSR) ISSN:2581-4281 Volume 3, Issue 6, June 2020

IJAMSR 3 (6) www.ijamsr.com CrossRef: https://doi.org/10.31426/ijamsr.2020.3.6.3414

International Journal of Advanced Multidisciplinary Scientific Research (IJAMSR) ISSN:2581-4281

\begin{tabular}{|c|c|c|c|}
\hline Sr. & Parameter & Old trend & Current trend \\
\hline 1 & Cost & $\begin{array}{l}\text { Customer had no option to buy the product at the cost decided } \\
\text { by supplier. Because there were few options available in market }\end{array}$ & $\begin{array}{l}\text { Customer is looking for } \\
\text { reasonable cost }\end{array}$ \\
\hline 2 & Quality & Not too much aware about quality & $\begin{array}{l}\text { Customer sometimes pay } \\
\text { heavy cost, but not willing } \\
\text { to compromise about } \\
\text { quality }\end{array}$ \\
\hline 3 & $\begin{array}{l}\text { Response } \\
\text { time }\end{array}$ & $\begin{array}{l}\text { Customers had patience about the delivery. There was tolerance } \\
\text { about delay }\end{array}$ & $\begin{array}{l}\text { Customer seeks quick } \\
\text { response and looking for } \\
\text { timely delivery }\end{array}$ \\
\hline 4 & $\begin{array}{l}\text { Customizati } \\
\text { on }\end{array}$ & $\begin{array}{l}\text { Customer was purchasing the available product in market. He } \\
\text { was not interested to demand as per his needs. }\end{array}$ & $\begin{array}{l}\text { Initially customer is } \\
\text { looking to satisfy his need. } \\
\text { Then he will go for } \\
\text { available products }\end{array}$ \\
\hline 5 & $\begin{array}{l}\text { Sources of } \\
\text { Information }\end{array}$ & $\begin{array}{l}\text { Very few sources were available for customer to collect the } \\
\text { information }\end{array}$ & $\begin{array}{l}\text { Due the social media } \\
\text { customer is quickly getting } \\
\text { the information. }\end{array}$ \\
\hline 6 & $\begin{array}{l}\text { Modes of } \\
\text { payment }\end{array}$ & $\begin{array}{l}\text { Fewer modes like cash deposit were available to deposit the } \\
\text { payment }\end{array}$ & $\begin{array}{l}\text { Various methods of } \\
\text { payment were available } \\
\text { due to E-banking }\end{array}$ \\
\hline
\end{tabular}

\begin{tabular}{|c|c|c|c|}
\hline 7 & $\begin{array}{l}\text { After } \\
\text { service }\end{array}$ & $\begin{array}{l}\text { Customer was not aware about that or he was not so much } \\
\text { interested. }\end{array}$ & $\begin{array}{l}\text { Customer is asking for } \\
\text { after service }\end{array}$ \\
\hline 8 & Trust & In the name of brand customer always trusts. & $\begin{array}{l}\text { Tough there is brand } \\
\text { name, customer only } \\
\text { believes after his } \\
\text { satisfaction. }\end{array}$ \\
\hline 9 & Variety & Customer was not interested in variety & $\begin{array}{l}\text { Customer is looking for } \\
\text { variety }\end{array}$ \\
\hline 10 & Technology & Some fear was there to adopt the new technology & $\begin{array}{l}\text { Quickly adapting new } \\
\text { technology and scrapping } \\
\text { old one }\end{array}$ \\
\hline
\end{tabular}


IJAMSR 3 (6) www.ijamsr.com CrossRef: https://doi.org/10.31426/ijamsr.2020.3.6.3414

\section{Marketing Technology: Past And Future}

There's no denying that innovation had changed the manner in which that worldwide residents get, translate and respond to information. With the ascent of the internet at the turn of the twenty-first century, and the fast evolution of gadgets that enable speedy and simple access to its millions of gateways, consumers are finding better approaches to cooperate with organizations and with items. Given these new types of purchaser dealer interactions, numerous professionals and people the same presently accept that the information age, encouraged by advancing advances, has reclassified the job of marketing.

The job of marketing has generally changed with time. Marketing's job moved to creating and overseeing client relationships [6]. Today, more than decade after this new job was received, marketers are as yet occupied with building these relationships. In spite of the fact that the job of marketing has not changed because of innovation, the power dynamic in purchaser vender relationships, corporate frames of mind toward the marketing function and marketing approaches have all been inseparably modified by the quick evolution of innovation. The ascent of the internet has been the absolute most adverse impetus in the difference in the power dynamic from marketers to consumers. Using the internet, consumers have accessed large numbers of information from around the globe information that is ageless, basic and unquestionable. With only a tick of a button consumers can increase significant bits of knowledge about organizations and their items. They can look at items, discover lower costs, read surveys and even speak with different clients about item quality and purchaser satisfaction. Significantly further, internet clients are not simply utilizing content, they are making and imparting to other people, taking into account uncommon exchanges of information and information.

With the explosion of social media, for example, Facebook, Twitter, Tumblr, Instagram and the sky is the limit from there, consumers can get to coordinate input about items both great and awful from their connections. On this day, a blog or video made by a disappointed client can get viral in only hours. Considerably more effective than the action of the post is the reaction it inspires in those it experiences. This move is consequently disposing of the notion of brand matchless 
IJAMSR 3 (6) www.ijamsr.com CrossRef: https://doi.org/10.31426/ijamsr.2020.3.6.3414

\section{International Journal of}

Advanced Multidisciplinary Scientific Research (IJAMSR) ISSN:2581-4281

quality and brand steadfastness. As consumers look for an incentive at lower costs, brands are quick turning out to be products, presenting difficulties to the modern advertiser [7]. Today marketers guarantee brand trustworthiness. Since essentially making an item and pushing it upon clients never again works. Marketing is presently compelled to tune in to clients and discover methods for converting interactions into personalized, esteem loaded items that are moderate and superior to that of contenders. It should likewise discover methods for injecting its items with best help that can win digital brand ministers, who can communicate brand an incentive to their connections. Whatever the methodology, the truth remains that organizations are never again responsible for the communication procedure, their image message and even their valuing models on occasion. Innovation has offered path to the ascent of the conscious consumer. Marketing had been named as one of the four key functional territories of a business.

Anyway with marketing's job changing in the late 1990's to building client relationships, there has been a resulting change in the manner the general function is respected inside corporations. Today, marketing is perceived as the paste that ties organizations together [8]. It is marketing's business projections that help operations in deciding production levels and account in arranging spending plans. It is a similar marketing, whose prescient examination of client patterns and needs that enables innovative work to decide new tasks for item advancement. Indispensable to this cross-functional view is the conviction that marketing has become everyone's business.

With expanded access to information energized by the utilization of versatile digital advances, consumers are never again trusting that marketers will contact them. Today, consumers keen on searching additional information may connect with an organization, both online and disconnected. The people and frameworks with which these consumers draw in are all touch focuses. They give substantial wellsprings of information that assist organizations with making dynamic client profiles and typesets. These can thus be utilized to create personalized messages and items, which organizations can later market to these very clients [9]. Two drivers are key affecting everything here. The first is that consumers never again separate between client assistance and item. Similarly as innovation has 
IJAMSR 3 (6) www.ijamsr.com CrossRef: https://doi.org/10.31426/ijamsr.2020.3.6.3414

coordinated the world, putting it at each consumer's fingertips, so too have their convictions of client assistance, item, marketing and business functions become incorporated as one. Consumers will make contact focuses with each part of the business, which implies these interfaces must be set up to connect with, that is, advertise their items and themselves. In this lies the second driver.

Since marketing's job is to manufacture client relationships, and in light of the fact that touch focuses don't only occur between the marketing office and clients, different offices should likewise be imbued with the marketing function. With the expanding utilization of Customer Relationship Management frameworks inside organizations that help to coordinate and change the information from these touch focuses, it to dynamic techniques, it has gotten significantly increasingly significant for marketing to be diffused all through each part of a business. Organizations, for example, Starbucks and Zappos that have grasped this new marketing concept have lived to encounter gigantic accomplishment in this profoundly straightforward world. Understanding that the intensity of the message never again laid in the medium, but instead in the manners by which the medium is utilized, most marketers started rebranding their business, concentrating their assets on building intuitive relationships with consumers in online networks as opposed to pushing media battles.

Well first of all, marketers are never again guided by the proverb, "a prevalent item will sell itself." Understanding how the internet has encouraged globalization, and the straightforwardness at which clients can source and buy items from anyplace on the planet, marketers have gotten progressively hearty, deliberately positioning themselves any place their clients are situated in the digital circle. At these new touch focuses, the canny advertiser tunes in to his client, assembles improved, personalized information, which he controls to give important solutions, not push his item unto the client. The present advertiser comprehends that content is top dog and that to endure, marketers must become multi-channel distributers also. As clients continuously scan for crisp information, marketers are currently looked with the test of continuously nourishing that need and doing so utilizing the correct configuration, degree and tone. Creating opensource content is basic to this technique, as is discovering approaches to guarantee that the 
IJAMSR 3 (6) www.ijamsr.com CrossRef: https://doi.org/10.31426/ijamsr.2020.3.6.3414

\section{International Journal of}

Advanced Multidisciplinary Scientific Research (IJAMSR) ISSN:2581-4281

messages are syndicated and incorporated with different destinations through connections. Websites are presently loaded up with online journals, through which marketers offer bits of knowledge not really about their items or administrations yet more so about their clients most squeezing concerns - all with expectations of supporting the purchaser vender relationship and building brand steadfastness.

Understanding the apparent worth that clients credit to personalized messages, the act of mass marketing has taken a rearward sitting arrangement, to broadened promoting that is established in the notion that quality client relationships mean more noteworthy returns than simply insignificant relationship. In view of the straightforwardness and recurrence of distribution of client and advertiser created content, marketers are additionally "brand vigilantes," compelled to keep a careful gaze for brand defamation online. Similarly as one great audit composed by a client, which is imparted to connections in an online network can support a brand's reputation and client base, so too can negative criticism offered by clients.
By a long shot the most convincing difference in the way to deal with the marketing function since the turn of the century has been the move from Outbound Marketing to Inbound Marketing. Working from the encounters gained from working together, businesses have come to perceive the staggering favorable circumstances of pulling clients toward their item, as opposed to pushing their items toward their clients. Outbound Marketing, characterized by its emphasis on barraging consumers with messages through print, radio and television promotions, just as those irritating telemarketing and spam email messages, are exorbitant, yet are essentially no longer compelling. The realization of the failure of traditional marketing to cut it on its own has offered route to the draw marketing marvels.

This new procedure gives huge advantages to businesses. Inbound Marketing pulls clients toward a brand by providing esteem loaded content, for example, white papers, eBooks, information designs and more that enable marketers to procure their way into clients internal circles. From here marketers can rub the requirements of their clients and addition advantaged, personal information that they can 
IJAMSR 3 (6) www.ijamsr.com CrossRef: https://doi.org/10.31426/ijamsr.2020.3.6.3414

use to reclassify and indicate their market portions, decide significant leads and make personalized messages and items. As content is nourished through locales like Twitter, Facebook and news aggregators, for example, Reddit.com and Digg.com, its compass can increase making its message viral. With web indexes being the go to apparatus for consumers looking to explain or accumulate information, marketing is additionally accused of the responsibility of guaranteeing that their content isn't only client centered, yet web index upgraded by its utilization of explicit promotion words.

Through social media and the internet, marketing's demeanor toward the improvement of ads and promotions has additionally changed. Prior to the adjustment in approach, marketing offices relied upon inside imagination and acumen, or that of redistributed contracts, to help conceptualize publicizing efforts. With publicly supporting, organizations can continue fortifying their client relationships and accomplish winning notices at a less expensive rates. This carries us to the issue of cost, and the manners by which this new marketing approach influences the reality. In contrast to traditional Outbound marketing, Inbound Marketing, on account of its utilization of digital advancements that take into consideration more noteworthy reach and explicitness, offers more prominent, quantifiable returns, at less expensive expenses. Inbound Marketing apparently cost $62 \%$ less per lead than outbound marketing.

The utilization of business knowledge, prescient investigation and Customer Relationship Management frameworks and other programming applications and projects are altogether inalienable in this new marketing approach. These innovations enable organizations to rapidly sort, investigate and interpret the assortment of information they access from the expanding contact focuses with their clients. Together with the evolution of the internet and digital gadgets that enable fast solid access to its entryways, the marketing approach, not its job, will continue to develop. In the coming years, it won't be weird to see marketing's function getting increasingly weakened with information innovation, bringing forth marketing-tech groups. CMOs and CIOs will team up on more noteworthy ventures, with the previous dropping more spending bucks on information innovation than the last mentioned. Humankind's fascination 
IJAMSR 3 (6) www.ijamsr.com CrossRef: https://doi.org/10.31426/ijamsr.2020.3.6.3414

with portable innovations, configured with GPS, 4G and Wi-Fi abilities, joined with their hunger for information on-the-go will channel attention away from traditional media outlets to handheld gadgets. With the should be the place the client is, marketing will be accused of the responsibility of making content, yet arranging it to meet the versatile stage.

This in any case, won't mean the passing of traditional Outbound Marketing and in this way the recorded function of marketing. Since there will consistently be separated clients; since old frameworks can be repurposed; and on the grounds that even well known Inbound Marketing champs Hub Spot currently confess to utilizing a blend of both Inbound and Outbound Marketing, thinking marketing's function will be part, regardless of whether equitably or unevenly, amongst the two methodologies. One thing is sure that Marketing's job of creating quality client relationships will drive its function to emphatically associate with the changing practices of its clients. Their practices and propensities whether driven by innovation, globalization, or different patterns, will coordinate the continuous evolution of the marketing function. Innovation has constantly changed how marketing functions. What is diverse today is the extraordinary pace of progress in the both the advancement of marketing instruments and the escalation of expectations for better encounters from clients.

\section{Conclusion}

Due to the effects of Globalization-Internet and portable innovation and social media, the Marketing part is going through an inquisitive and intriguing stage. You can't scrap the old strategies, and yet you need to acknowledge and make material the new procedures. There are quick changes in Marketing systems, techniques and devices. The Industries need to get them all of a sudden, in the event that they need to continue in competition. Thus rather than Production the Marketing division is positioning halfway in the organization. The enterprises need to contribute more money for the marketing division. In past the expressions like "Modern Techniques" were connected only with production division. Be that as it may, presently they are similarly significant if there should arise an occurrence of Marketing division moreover. Social media marketing is developing quickly to advance the items and administrations in online through different 
IJAMSR 3 (6) www.ijamsr.com CrossRef: https://doi.org/10.31426/ijamsr.2020.3.6.3414

social systems like LinkedIn, Facebook, twitter, Instagram and so on. Significant advantage of social media marketing, which brings about expanding benefit of your organization, is improving deals, in any case on the off chance that you claim an online shop or you need to urge individuals to visit your business a particular location. So fundamentally the organizations must embrace social media systems to continue in the market. A vocation in social media is probably going to ne quick paced and testing, however it tends to be very fulfilling, monetarily and something else. If you know what kind of position to look for, social media could just be the source of your dream career.

\section{REFERENCES}

1) Ace Metrix, 2011. Celebrity Advertisements: Exposing A Myth Of Advertising Effectiveness. [online]. Available at: . [Accessed 30 September 2013].

2) Armstrong, G., Kotler, P., Harker, M. and Brennan, R., 2012. Marketing an introduction. 2nd edition. Essex: Pearson Education Limited.

3) Bharadwaj, A., El Sawy, O. A., Pavlou, P. A. and Venkatrama, N., 2013. DIGITAL BUSINESS STRATEGY: TOWARD A NEXTGENERATION OF INSIGHTS. MIS Quarterly. Vol. 37 No. 2, pp. 471-482/June 2013. [online] Available at: . [Accessed 11
October 2013].

4) BLS, Bureau of Labor Statistics, 2012. Consumer Expenditures -2012. News Release. [Online] Available at: . [Accessed 12 September 2013].

5) Desilver, D., 2013. 5 Facts about Tumblr. PewResearchCenter. [online] Available at: . [Accessed 15 September 2013].

6) Duggan, M. and Brenner, J., 2013. The Demographics of Social Media Users 2012. Pew Research Center. [Online] Available at: . [Accessed 26 September 2013]

7) Hartman, 2010. Beyond Organic \& Natural 2010. Resolving Confusion in Marketing Food and Beverages. The Hartman Group Syndicated Study. [Online] . [Accessed 25 September 2013].

8) Jacobsen, L., A., Mather, M., 2011. ProQuest: A POST-RECESSION UPDATE ON U.S. SOCIAL AND ECONOMIC TRENDS. [Online] Availlable at: . [Accessed 12 September 2013].

9) Kotler, P., Armstrong, G., Harris, L. C. and Piercy, N., 2013. Principles of Marketing. European Edition. Harlow: Pearson Education.

10) Kril, J., 2013. Statistics and Facts about Online Shopping. Statista. [Online] Available at: [Accessed 6 October 2013].

11) Petit, C., Dubois, C., Harand, A. and Quazzotti, S., 2011. A new, innovative and marketable IP diagnosis to evaluate, qualify and find insights for the development of SMEs IP practices and use, based on the AIDA approach. World Patent Information. Mar 2011, Vol. 33 Issue 1, p42-50. $9 p$. 